\title{
Sugarcane Bagasse and Castor Oil Polyurethane Adhesive-based Particulate Composite
}

\author{
Juliano Fiorelli", Diogo de Lucca Sartori, Julio Cesar Machado Cravo ${ }^{\text {a }}$, Holmer Savastano Junior, \\ João Adriano Rossignolo ${ }^{\mathrm{a}}$, Maria Fátima do Nascimento ${ }^{\mathrm{b}}$, Francisco Antonio Rocco Lahr \\ ${ }^{a}$ Faculty of Animal Science and Food Engineering, University of São Paulo - USP, \\ Av. Duque de Caxias Norte, 225, CEP 13635-900, Pirassununga, SP, Brazil \\ ${ }^{\mathrm{b}}$ São Carlos School of Engineering, University of São Paulo - USP, Av. Trabalhador São-Carlense, \\ 400, CEP 13566-590, São Carlos, SP, Brazil
}

Received: November 20, 2011; Revised October 9, 2012

This paper discusses the potential use of sugarcane bagasse in two different fiber lengths ( $5 \mathrm{~mm}$ and $8 \mathrm{~mm}$ ) of the same density as a raw material for the production of particleboards, using castor oil-based two-component polyurethane adhesive. The quality of the product that can be manufactured industrially was evaluated based on density, thickness swell (TS), absorption (WA), modulus of elasticity (MOE), modulus of rupture (MOR) in static bending and internal bond (IB), according to the Brazilian NBR 14.810:2006 standard. The results revealed a significant difference between the particleboards made with 5-mm-long fibers and those made with 8-mm-long fibers. An analysis by scanning electron microscopy (SEM) indicates that the interparticle spaces are filled with castor oil-based two-component polyurethane adhesive, contributing to improve the physicomechanical properties of the particleboards. A durability assessment based on accelerated aging tests shows that waterproofed particleboards can be used in moist environments.

Keywords: industrial wastes, sustainability, composites, particleboard, adhesive

\section{Introduction}

A proposed alternative destination for agricultural wastes is to use them for the manufacture of particulate composites, or particleboards. These particleboards are usually manufactured from wood particles bound together with synthetic adhesives or other binders, which are pressed under heat until the adhesive has cured ${ }^{1}$.

Basically, these particleboards can also be made of any lignocellulosic material that gives them high strength and a predetermined specific weight, since the chemical composition of lignocellulosic materials is similar to that of wood, especially hardwoods which have lower lignin content and higher pentose hemicellulose content $t^{2-10,20,21,23,24}$.

Brazil's sugarcane production has expanded considerably, particularly in the state of São Paulo. According to the National Food Supply Company - CONAB, the state of São Paulo will account for $54.23 \%$ of the total area in the country cultivated with sugarcane in $2011 / 2012$, reaching 8 million ha, and representing $64 \%$ of the sugarcane produced in the central southern region. In 2010, São Paulo harvested a record crop of $360 \mathrm{MT}$ of sugarcane, an $8.4 \%$ increase over the preceding crop.

However, the sugar and alcohol industry produces large quantities of wastes, including sugarcane bagasse. São Paulo itself produces about $108 \mathrm{MT}$ of bagasse annually, burning $60 \%$ to produce energy and discarding $40 \%$. Burning adds no value to the wastes and contributes to global warming and the greenhouse effect.

*e-mail: julianofiorelli@usp.br
In recent years, efforts have intensified to study the best use of lignocellulosic wastes for the production of new materials such as particleboards ${ }^{8}$. The use of lignocellulosic wastes contributes to mitigate environmental impacts through the production of new materials aimed at sustainability. Another alternative is the use of sugarcane bagasse to manufacture particleboards. This material has high cellulose content which exerts a positive effect on the particleboard bonding process ${ }^{11}$.

Barros Filho et al. ${ }^{12}$ conducted a study on particleboards made with sugarcane bagasse using urea formaldehyde (UF) and melamine formaldehyde (MF) resins. Particleboards were produced with a mixture of sugarcane bagasse and pine or eucalyptus particles, with and without paraffin in the formulation. Nine different types of particleboards, all containing $9 \%$ of resin in the mix, were produced at a temperature of $160{ }^{\circ} \mathrm{C}$ and under a pressure of 4.0 MPa. The physical characteristics of the particleboards complied with the ASTM CS 236-66 standard for medium density chipboards, and in most cases, showed better results than others reported in the literature. However, when subjected to mechanical testing, these particleboards did not comply with the aforementioned standard, and in most cases, the results were close to or worse than those reported in the literature.

$\mathrm{Xu}$ et al. ${ }^{13}$ studied bagasse particleboards (BPBs) using polymeric methylene diphenyl diisocyanate (pMDI) resin as binder and wax emulsion as dimension stabilizer. A factorial experiment was conducted to measure the effects of wax and pMDI resin content on the particleboard's 
dimensional stability and mechanical properties. The data were compared with corresponding properties specified in the ANSI A208.1 standard for commercial M3 grade wood-based particleboard. Wax-sizing improved the linear expansion (LE) of the particleboards produced with the two different proportions of pMDI resin tested in their research, and all the LE values remained below the critical value of $0.35 \%$. The use of wax significantly reduced 24 -hour water absorption and thickness swelling compared to the control particleboards without wax. Moderate levels of wax-sizing also proved to have a positive effect on the properties of long-term water absorption and thickness swelling. The mechanical properties of all the particleboards far exceeded the minimum values specified in the ANSI A208.1 standard. As expected, the overall properties of the 5\% pMDI BPBs were better than those of the $3 \%$ pMDI particleboards.

The agglomerate panel industry in Brazil uses mostly wood shavings from reforested pine and some eucalyptus species, resulting in a higher quality product due to better control of the homogeneity of raw material. However, in view of Brazil's agricultural boom and the resulting increase in agricultural wastes, a recent alternative for particleboard production may be the use of agroindustrial lignocellulosic wastes to replace solid wood particles in the manufacture of composite panels.

Several studies suggest that sugarcane bagasse is a promising material for the manufacture of particleboards. However, formaldehyde emissions pose a serious health risk and the use of urea-formaldehyde and phenol-formaldehyde adhesives to produce particleboards involves high energy consumption ${ }^{6}$. Nevertheless, there is a global trend towards biodegradable, non-polluting and renewable products. According to Araújo ${ }^{14}$, this trend has led to further research, resulting in castor oil-based polyurethane adhesive, a resin with characteristics of sustainability and other advantages, e.g., lower processing temperature, and hence, lower consumption of energy in the production of particleboards.

In this context, this paper evaluates the feasibility of producing particleboards made of sugarcane bagasse particles with two different fiber lengths $(5 \mathrm{~mm}$ and $8 \mathrm{~mm}$ ) and a density of $1.0 \mathrm{~g} . \mathrm{cm}^{-3}$, as well as the efficiency of these particleboards manufactured with castor oil polyurethane adhesive. The novelty of this work stems from the evaluation of the physicomechanical and durability properties of particleboards made of agroindustrial wastes (sugarcane bagasse) with different fiber lengths and castor oil polyurethane adhesive.

\section{Material and Methods}

\subsection{Production of particleboards}

Sugarcane bagasse particleboards were prepared using a heated automatic press with a load capacity of $100 \mathrm{MT}$, as described by Maloney ${ }^{15}$. The sugarcane bagasse was collected from a processing plant (Figure 1a) and dried to a moisture content of 2 to $3 \%$. The bagasse was used in fiber lengths of $5 \mathrm{~mm}$ and $8 \mathrm{~mm}$. The particleboards were prepared with $10 \%$ to $15 \%$ of castor oil-based two-component polyurethane adhesive manufactured by Plural Brazil. Table 1 gives further details.
The particles ( $5 \mathrm{~mm}$ and $8 \mathrm{~mm}$ long) were mixed with the adhesive in a planetary mixer (Figure 1b). After mixing, the material was placed in a mold (Figure 1c), which was then inserted into the hydraulic press (Figure 1d) and pressed for ten min under $50 \mathrm{kgf} . \mathrm{cm}^{-2}$, at a temperature of up to $100^{\circ} \mathrm{C}$. Five particleboards were prepared with nominal dimensions of $40 \times 40 \mathrm{~cm} \times 10 \mathrm{~mm}$ thickness. From these particleboards 10 specimens were taken for each physicomechanical test, as recommended by the Brazilian NBR 14810:2006 standard for Plywood Sheets ${ }^{16}$. This standard was chosen due to the similarity between the sugarcane bagasse particleboards produced in this study and wood panels.

\subsection{Physicomechanical characterization}

The performance of the particleboards was evaluated by physical and mechanical tests according to the Brazilian NBR 14810:2006 standard for Plywood Sheets ${ }^{16}$. A completely random design (CRD) was used with three treatments (Table 1). The properties evaluated were the thickness swelling (TS), water absorption (WA), modulus of rupture (MOR), modulus of elasticity (MOE) and internal bond (IB). These properties were evaluated before and after the accelerated aging test. The average values were compared by a multiple comparison test (Tukey) when the ANOVA showed a significance level of $\mathrm{p} \leq 0.05$.

\subsubsection{Thickness Swelling (TS)}

The thickness swell tests were conducted according to the Brazilian ABNT NBR 14810:2006 standard ${ }^{16}$. Thickness swelling is calculated from the difference in a specimen's thickness before and after soaking in water for 24 hours. This swelling was measured using a digital caliper with a precision of $0.01 \mathrm{~mm}$. The percentage of thickness swelling was calculated using Equation 1:

$\operatorname{TS}(\%)=\left[\frac{T f-T i}{T i}\right] * 100$

where: Tf is the final thickness after soaking for 24 hours and $\mathrm{Ti}$ is the initial thickness.

\subsubsection{Water Absorption (WA)}

The water absorption tests were conducted according to the ABNT NBR 14810:2006 standard ${ }^{16}$. The samples before and after accelerated aging were soaked in water for 2 hours and 24 hours. Water absorption was calculated using Equation 2.

$\mathrm{WA}(\%)=\left[\frac{W f-W i}{W i}\right] * 100$

where: Wf is the final weight after soaking for 2 hours and 24 hours and Wi is the initial weight.

Table 1. Experimental program for sugarcane bagasse particleboard.

\begin{tabular}{ccccc}
\hline Treatment & $\begin{array}{c}\text { Density } \\
\left(\mathbf{g . c m}^{-3}\right)\end{array}$ & $\begin{array}{c}\text { Fiber } \\
\text { length } \\
(\mathbf{m m})\end{array}$ & $\begin{array}{c}\text { Adhesive } \\
\text { type }\end{array}$ & $\begin{array}{c}\text { Accelerated } \\
\text { aging test } \\
\text { ASTMD 1037 } \\
\text { Standard }\end{array}$ \\
\hline T1 & 1.0 & 5 & Castor oil & --- \\
T2 & 1.0 & 8 & Castor oil & --- \\
T3 & 1.0 & 8 & Castor oil & 6 cycles \\
\hline
\end{tabular}




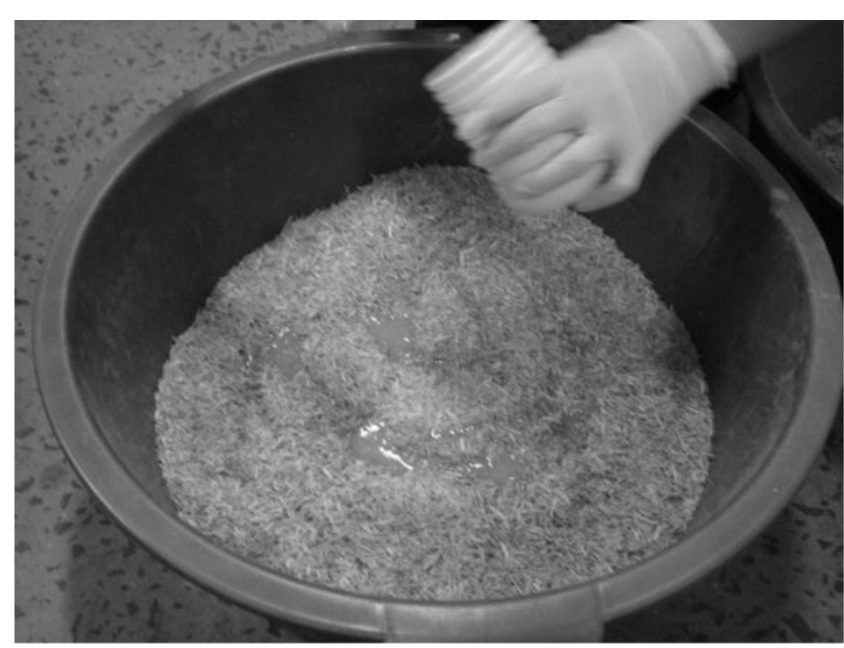

(a)

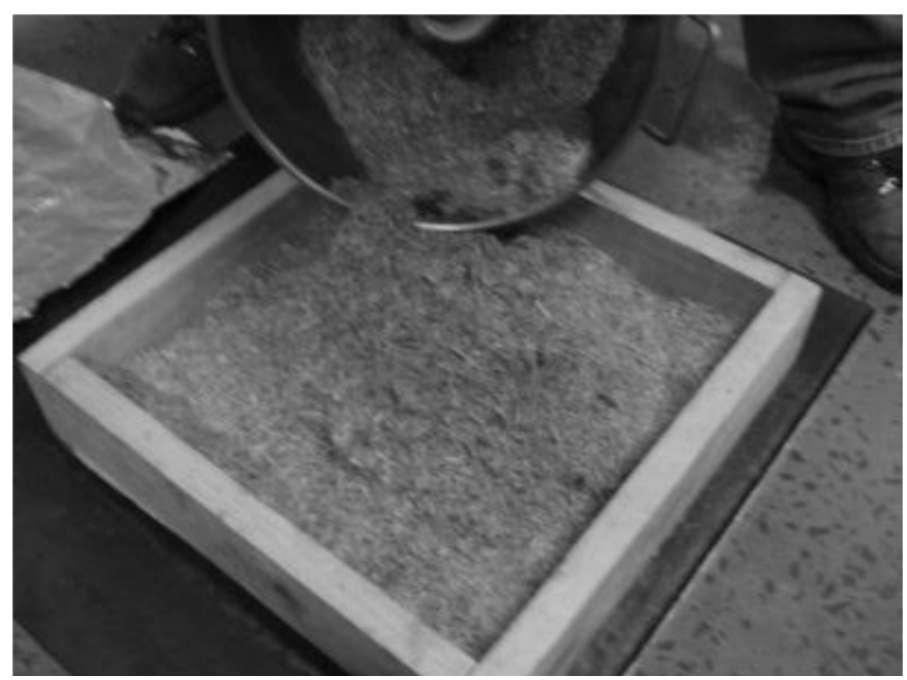

(c)

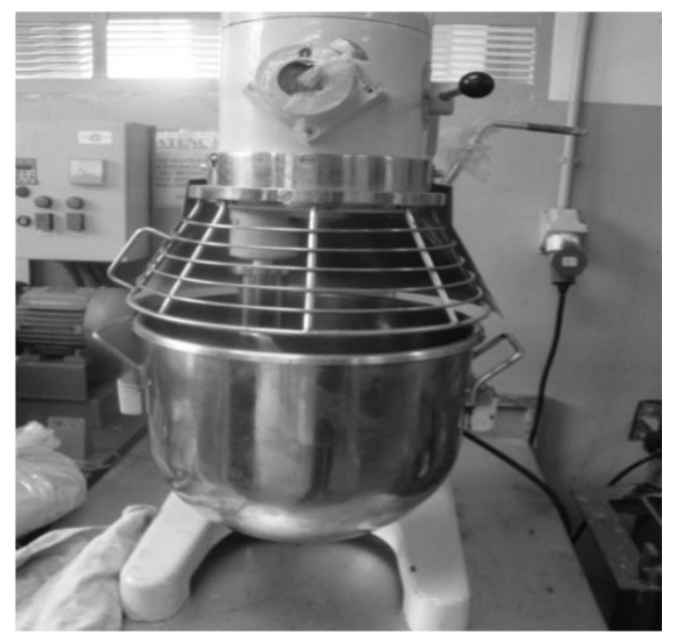

(b)

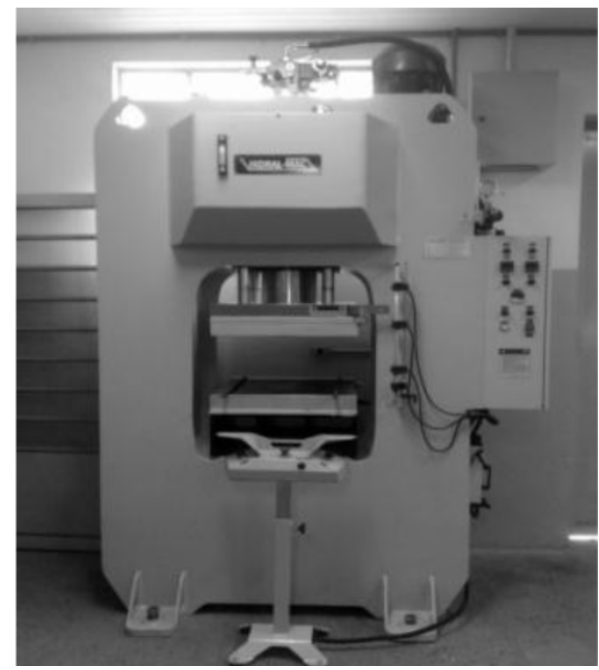

(d)

Figure 1. Production steps of particleboard.

\subsubsection{Mechanical testing}

The internal bond and flexural tests (Figure 2) were conducted using a universal testing machine at room temperature, according to the ABNT NBR 14810:2006 standard ${ }^{16}$. The loading rate applied to measure the bond strength was controlled at $4 \mathrm{~mm} / \mathrm{min}$. Modulus of rupture (MOR) and modulus of elasticity (MOE) were determined by a three-point bending test in the universal testing machine operating with a load cell capacity of $5 \mathrm{kN}$. A total of ten specimens were prepared and tested.

\subsection{Durability analysis}

The durability of sugarcane bagasse and castor oil-based two-component polyurethane adhesive particleboards was evaluated according to the ASTM D 1037:1996 Standard Test Method for Evaluating Properties of Wood-Base Fiber and Particle Panel Materials ${ }^{17}$. The accelerated aging test involves the six steps illustrated in Figure 3 . Five test specimens were prepared with dimensions of $250 \times 50 \times 10 \mathrm{~mm}$ and protected with waterproofing (coating) material (castor oil-based two-component polyurethane adhesive) to improve durability. After the accelerated aging test, the specimens were stored at $65 \%$ relative humidity and $20{ }^{\circ} \mathrm{C}$ room temperature for 48 hours before determining their physical and mechanical characteristics.

\section{Results and Discussion}

This section presents the results of the physical and mechanical characterization of the sugarcane bagasse particleboards (treatments T1, T2 and T3). Average experimental values of density, water absorption, thickness swelling and mechanical properties (MOR, MOE and IB) and their coefficients of variation are presented.

The results were compared with those recommended by the standards NBR 14810:2006 ${ }^{16}$ and ANSI A208.1:1993-Mat-formed wood particleboard: Specification ${ }^{18}$. This comparison is justified based on the similarity between the product developed in this study and wood particleboards. 


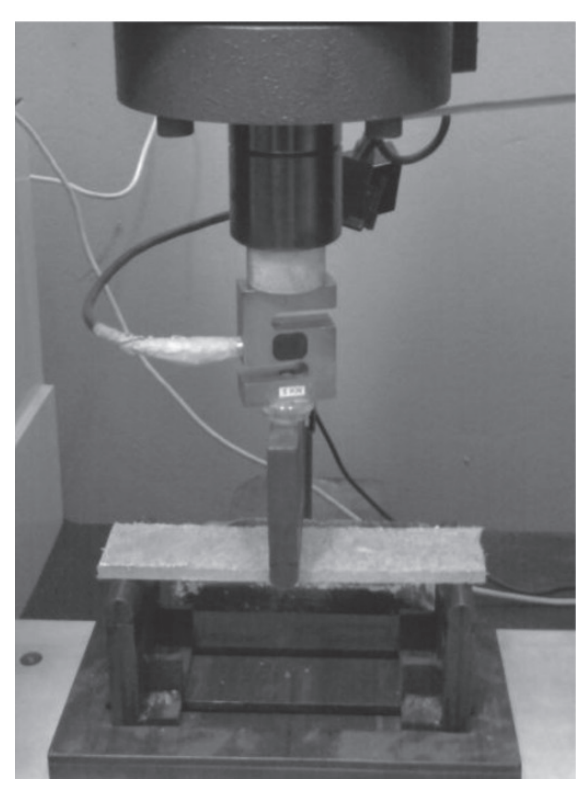

(a)

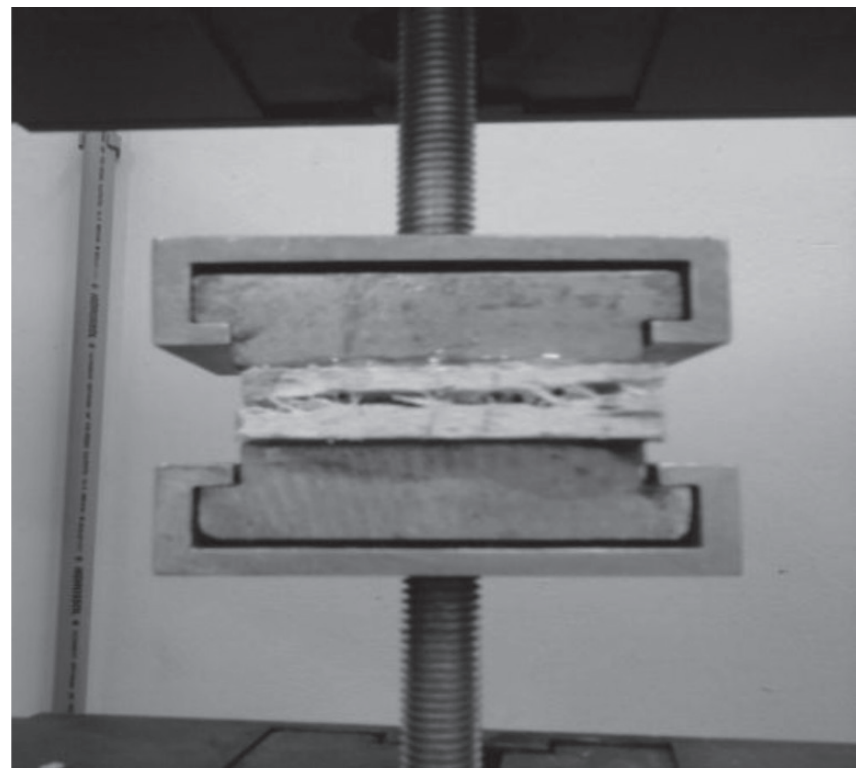

(b)

Figure 2. a) Flexural and b) IB testing of sugarcane bagasse particleboard.

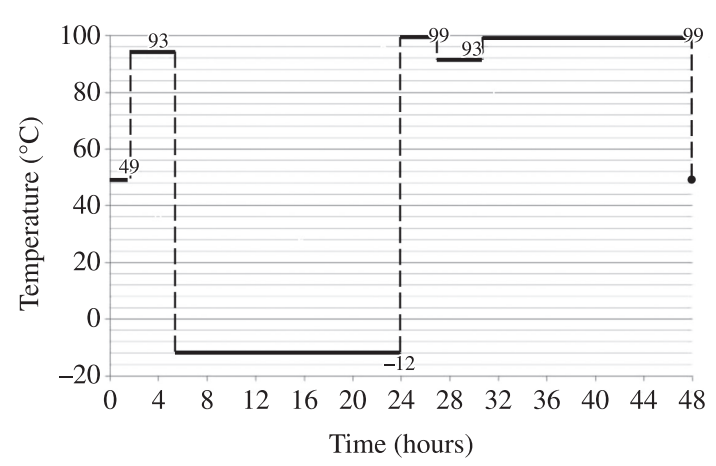

Figure 3. Phases of the ASTM D 1037 accelerated aging test.

\subsection{Physical properties}

One of the obstacles to the use of sugarcane bagasse particleboards is their low dimensional stability, which stems from their high tendency to absorb water ${ }^{19}$. Figure 4 shows the variation in the percentage of water absorption (24 hours) for specimens of the three treatments. The particleboards produced with $5 \mathrm{~mm}$ fibers (T1) showed higher water absorption than those prepared with $8 \mathrm{~mm}$ fibers (T2). This can be explained by the microstructure formed between the particles $(5 \mathrm{~mm}$ and $8 \mathrm{~mm}$ ) and the castor oil-based two-component polyurethane adhesive (Figures 10 and 11). Another possible explanation has to do with the dispersion of the adhesive among the particles. The light area in Figure 10 (T1) depicts a point where there is a concentration of adhesive. The particleboard subjected to accelerated aging, T3, showed a lower water absorption rate after 24 hours than T2. This is most likely because the accelerated aging test already exposes specimens to varying levels of water content under extreme temperature conditions.

The water absorption rates reached in treatments $\mathrm{T} 1, \mathrm{~T} 2$ and $\mathrm{T} 3$ were lower than the results reported by

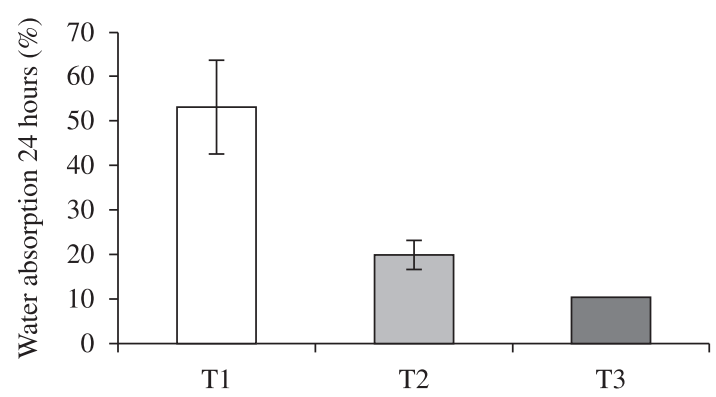

Figure 4. Water absorption of the sugarcane bagasse particleboard.

Barros Filho et al. ${ }^{12}$. The difference in these results is due to the castor oil-based polyurethane adhesive used in this work and the adhesives evaluated by the aforementioned authors (urea formaldehyde and melamine formaldehyde), as well as the dimensions of the particles.

The thickness swell tests provided information about the bonding conditions of the particleboards after immersion in water. In industrial settings, these tests are performed systematically for product quality control.

Figure 5 shows the differences in thickness swelling after 24 hours of immersion in water. Specimens subjected to accelerated aging presented lower values of thickness swelling. This is most likely because the accelerated aging test already exposes specimens to varying levels of water content under extreme temperature conditions. Particleboards made of $5 \mathrm{~mm}$ fibers (T1) showed higher thickness swelling values after 24 hours than those made of $8 \mathrm{~mm}$ fibers (T2). This result was attributed to the geometry of the particles (fibers) and the dispersion and expansion of the adhesive in the curing process (Figures 10 and 11). Prolonged soaking in water may cause leaching of water-soluble substances, and hence, reduction of resistance to decay. 
For wood particleboards, the ANSI A208.1:1999 standard ${ }^{18}$ establishes a maximum swelling value of $8 \%$ after 24 hours of immersion. In Figure 5, note that the T1, T2 and T3 particleboards present higher mean values than those established by this standard. However, these values are close to those reported by Barros Filho et al. ${ }^{12}$ and Fiorelli et al. ${ }^{20}$, who evaluated sugarcane particleboards.

Table 2 compares the physical and mechanical properties of particleboards with different fiber length (treatments T1 and $\mathrm{T} 2$ ).

As can be seen in Table 2, the properties WA, TS, MOE, and IB of the T1 and T2 particleboards produced with castor oil-based polyurethane resin show statistically significant differences $(p<0.05)$. These results indicate that T2 is more suitable for the production of sugarcane bagasse and castor oil resin particleboards. The T2 particleboard can be classified as a high-density material, according to the ANSI A208.1:1993 standard $^{18}$. This classification is important since the minimum MOE, MOR, IB and TS values are closely related with density.

\subsection{Mechanical properties}

Figure 6 correlates the MOR of the three different treatments (T1, T2 and T3). The specimens with different particle lengths (T1 and T2) showed higher values of MOR than the specimens subjected to the accelerated aging test (T3). These values are higher than recommended by the ABNT NBR 14810:2006 $6^{16}$ and ANSI A 208.1:1993 ${ }^{18}$ standards.

$\mathrm{T} 1$ and $\mathrm{T} 2$ showed higher MOR values than those reported by Battistelle et al. ${ }^{4}$, Mendes et al. ${ }^{6}$, Barros Filho et al. ${ }^{12}$, Tabarsa et al. ${ }^{23}$ and results similar to those reported by $\mathrm{Xu}$ et al. ${ }^{13}$ and Ashori et al. ${ }^{21}$, demonstrating that the density and the production process used in this study is consistent and that castor oil-based two-component resin is a viable adhesive material for the manufacture of sugarcane bagasse particleboards.

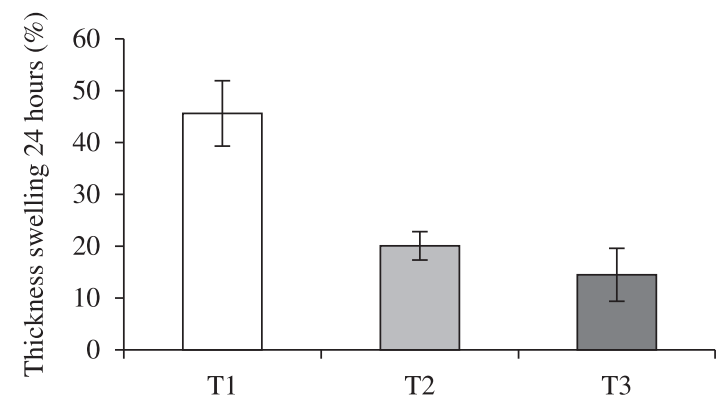

Figure 5. Thickness swelling of sugarcane bagasse particleboard after 24 hours of immersion in water.
Figure 7 compares the MOE values of different treatments (T1, T2 and T3). The T1 and T2 specimens show lower MOE values than those that underwent accelerated aging (T3). The sugarcane bagasse and adhesive castor oil particleboards (T1 and T2) clearly possess the minimum MOE requirements established by ANSI 208.1:1993 standard.

Figure 8 shows that the T2 specimens presented higher IB values than recommended by the ABNT NBR 14810:2006 ${ }^{16}$ and ANSI A. 208.1:1993 ${ }^{18}$ standards. These values were also higher than the $0.4 \mathrm{MPa}$ reported by Battistelli et al. ${ }^{4}$, 0.6 MPa obtained by Okino et al. ${ }^{2}$ and $0.5 \mathrm{MPa}$ present by Barros Filho et al. ${ }^{12}$, but similar to those results reported by $\mathrm{Xu}$ et al. ${ }^{13}$. These results indicate that the amount of adhesive employed was suitable in terms of IB. The IB analysis could not be conducted on the T3 particleboard due to the occurrence of degradation after accelerated aging.

\subsection{Durability analysis (T2 and T3)}

The durability of the particleboards was evaluated to verify the behavior of the material in response to accelerated

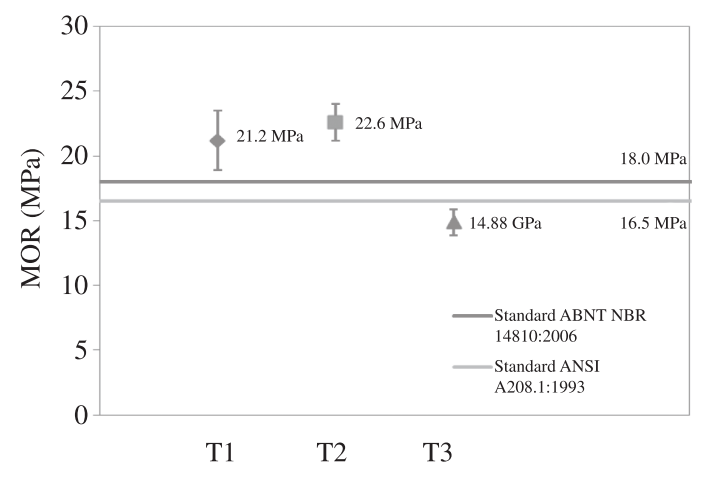

Figure 6. Average values of modulus of rupture.

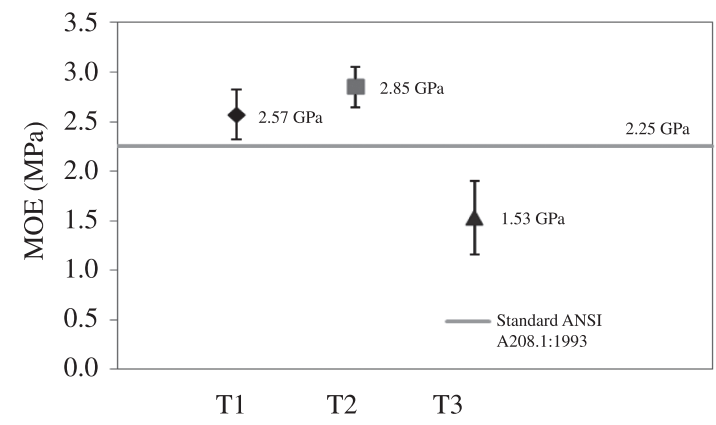

Figure 7. Average values of modulus of elasticity.

Table 2. Physical and mechanical properties - experimental values.

\begin{tabular}{ccccccc}
\hline Treatment & $\begin{array}{c}\text { Density } \\
\left(\mathbf{k g . c m}^{-3}\right)\end{array}$ & WA $(\mathbf{2 4}$ hours $)(\boldsymbol{\%})$ & TS $(\mathbf{2 4}$ hours $)(\boldsymbol{\%})$ & MOR (MPa) & MOE $(\mathbf{G P a})$ & IB $(\mathbf{M P a})$ \\
\hline T1 & $883^{\mathrm{a}}$ & $53.2^{\mathrm{a}}$ & $42^{\mathrm{a}}$ & $21.2^{\mathrm{a}}$ & $2.57^{\mathrm{a}}$ & $0.34^{\mathrm{a}}$ \\
CV & 7.0 & 19.9 & 23.2 & 10.7 & 10.0 & 79.0 \\
T2 & $947^{\mathrm{a}}$ & $20.1^{\mathrm{b}}$ & $20^{\mathrm{b}}$ & $22.6^{\mathrm{a}}$ & $2.85^{\mathrm{b}}$ & $1.18^{\mathrm{b}}$ \\
CV & 5.2 & 13.7 & 13.7 & 6.3 & 7.3 & 31.3 \\
\hline
\end{tabular}

*Mean values followed by the same letter in the same column do not differ in the Tukey test at a $5 \%$ level of significance. $* \mathrm{CV}=\mathrm{Variation}$ coefficient. 
aging. According to Lepage ${ }^{25}$, the main factors that cause the degradation of wood subjected to weathering are: moisture, sunlight and heat. The accelerated aging test evaluates two of these factors (moisture and heat). Table 3 describes the physical and mechanical properties of specimens with and without aging. It should be noted that the specimens under evaluation were protected with waterproofing (coating) material (castor oil-based two-component polyurethane adhesive) to improve their durability. This waterproofing material does not affect the mechanical properties. The statistical analysis indicates statistically significant differences $(\mathrm{p}<0.05)$ in both physical (WA and TS) and

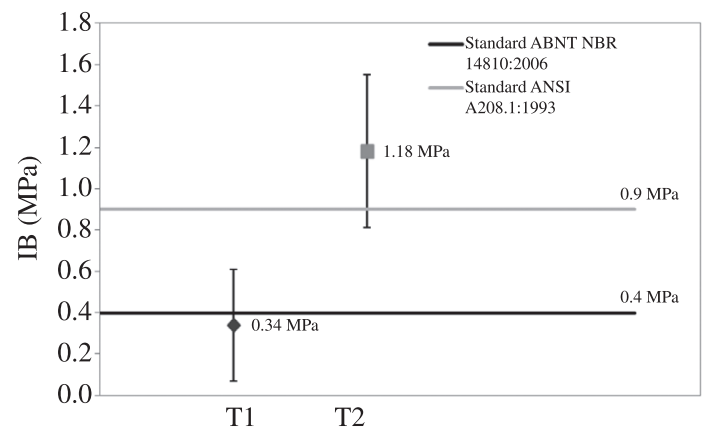

Figure 8. Average values of Internal Bond (IB).
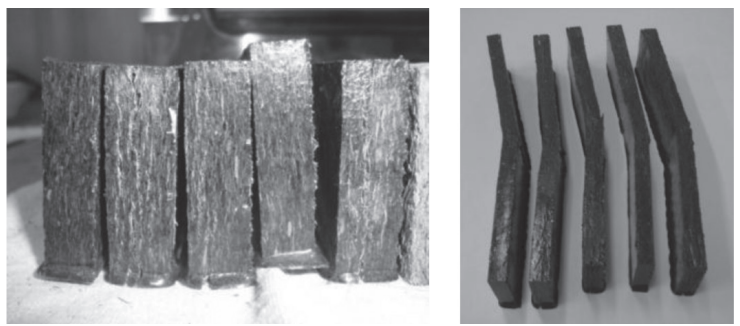

Figure 9. Modification of the physical behavior of composites after accelerated aging.

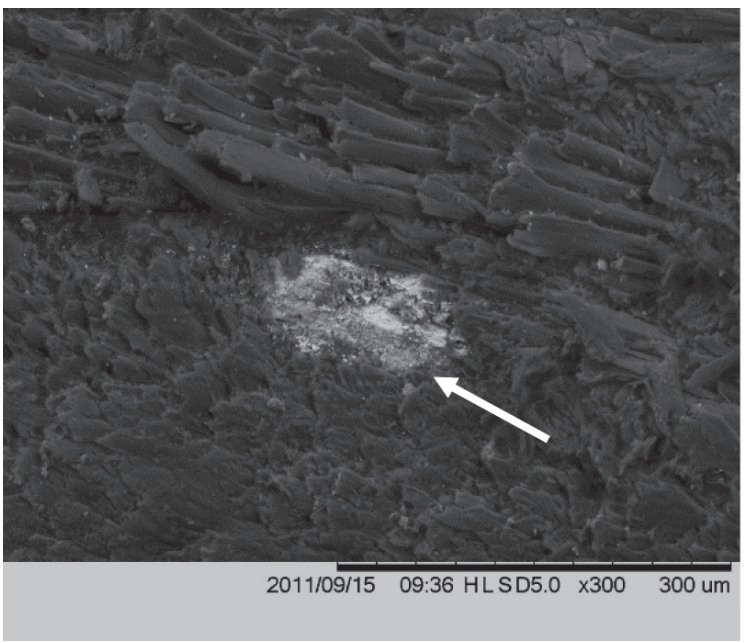

(a) mechanical (MOR and MOE) properties. Accelerated aging degraded the material, thus reducing its physicomechanical properties. T3 presented lower WA, which was attributed to the use of the waterproofing material. The durability of non-waterproofed specimens was not evaluated because the accelerated aging test (ASTM D 1037:1996) ${ }^{17}$ involves six steps (Figure 3), and non-waterproofed particulate composites made of agricultural wastes undergo $100 \%$ degradation. New studies are under way to adapt the methodology of the ASTM D 1037:1996 standard to particulate composites made of agricultural wastes ${ }^{26}$.

Figure 9 depicts sugarcane bagasse particleboards after accelerated aging. Note that these particleboards show little surface degradation. The figure also shows delamination on the composites after undergoing the stresses of six soaking, freezing, steaming and dry air cycles. This delamination in the composite caused an increase in thickness. The aged composite showed a higher percentage of water absorption than the specimens that were not subjected to accelerated aging.

\subsection{SEM analysis}

Figures 10, 11 and 12 depict SEM micrographs of the microstructures of the T1, T2 and T3 specimens, respectively. In Figure 11 (T2), under different magnifications, one can

Table 3. Physicomechanical properties - experimental values - durability analyses.

\begin{tabular}{ccccc}
\hline Treatment & $\begin{array}{c}\text { WA } \\
(\mathbf{2 4} \text { hours }) \\
(\boldsymbol{\%})\end{array}$ & $\begin{array}{c}\text { TS } \\
\mathbf{( 2 4} \\
\text { hours) } \\
(\boldsymbol{\%})\end{array}$ & $\begin{array}{c}\text { MOR } \\
(\mathbf{M P a})\end{array}$ & $\begin{array}{c}\text { MOE } \\
(\mathbf{G P a})\end{array}$ \\
\hline T2 & $20.1^{\mathrm{a}}$ & $20^{\mathrm{a}}$ & $22.6^{\mathrm{a}}$ & $2.85^{\mathrm{a}}$ \\
CV & 13.7 & 13.7 & 6.3 & 7.3 \\
T3 & $10.4^{\mathrm{b}}$ & $14.7^{\mathrm{b}}$ & $14.9^{\mathrm{b}}$ & $1.53^{\mathrm{b}}$ \\
CV & 10.8 & 11.2 & 24.1 & 11.5 \\
\hline
\end{tabular}

* Mean values followed by the same letter in the same column do not differ in the Tukey test at a $5 \%$ level of significance. $* \mathrm{CV}=$ Variation coefficient.

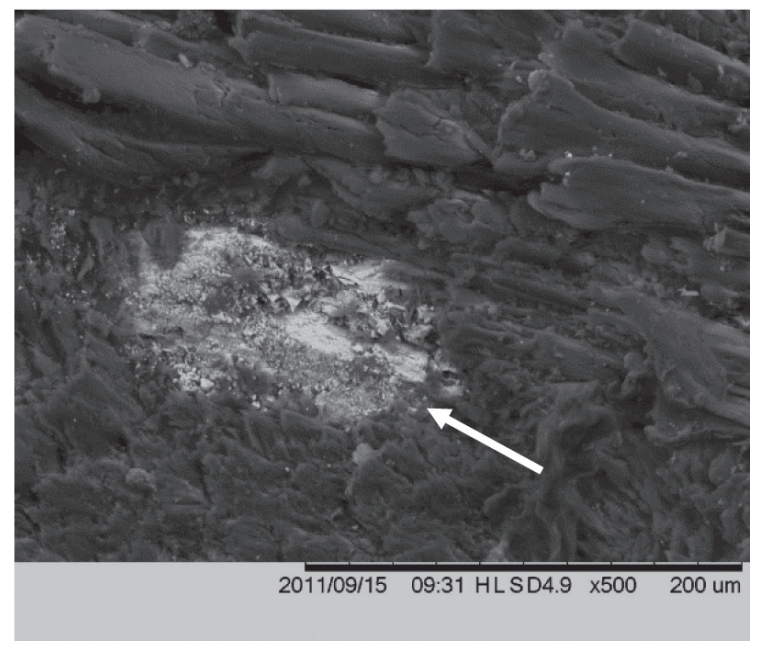

(b)

Figure 10. SEM micrographs of sugarcane bagasse and castor oil resin particleboard (T1): a) 300× magnification, and b) $500 \times$ magnification. 


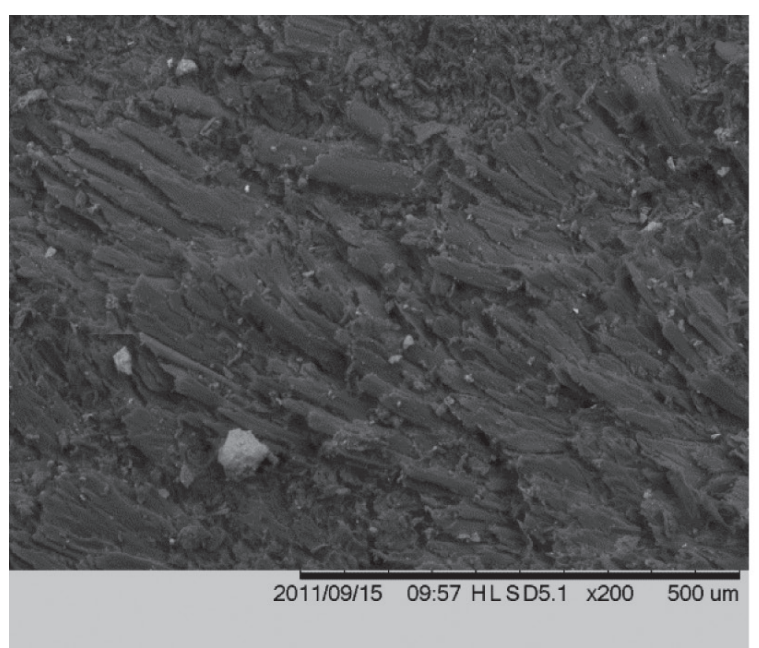

(a)

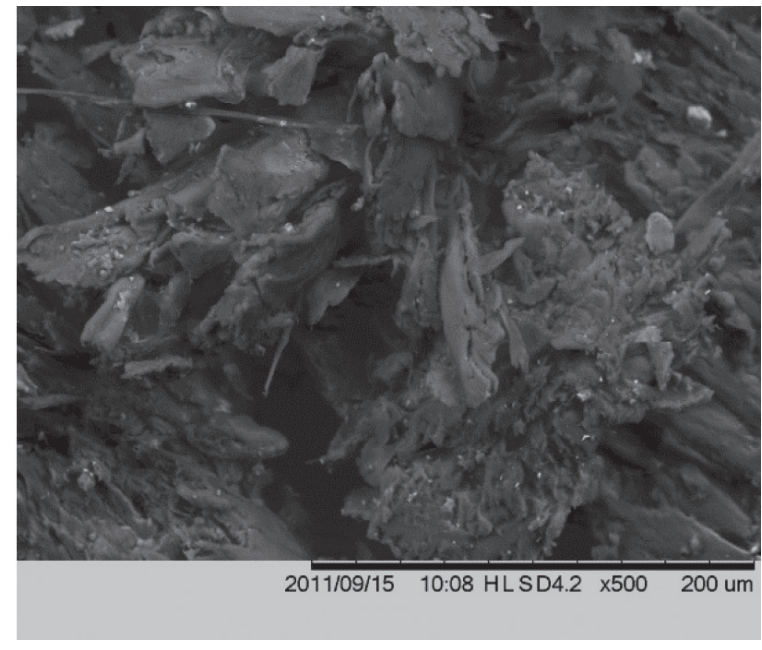

(b)

Figure 11. SEM micrographs of sugarcane bagasse and castor oil resin particleboard (T2): a) 200× magnification, and b) $500 \times$ magnification.

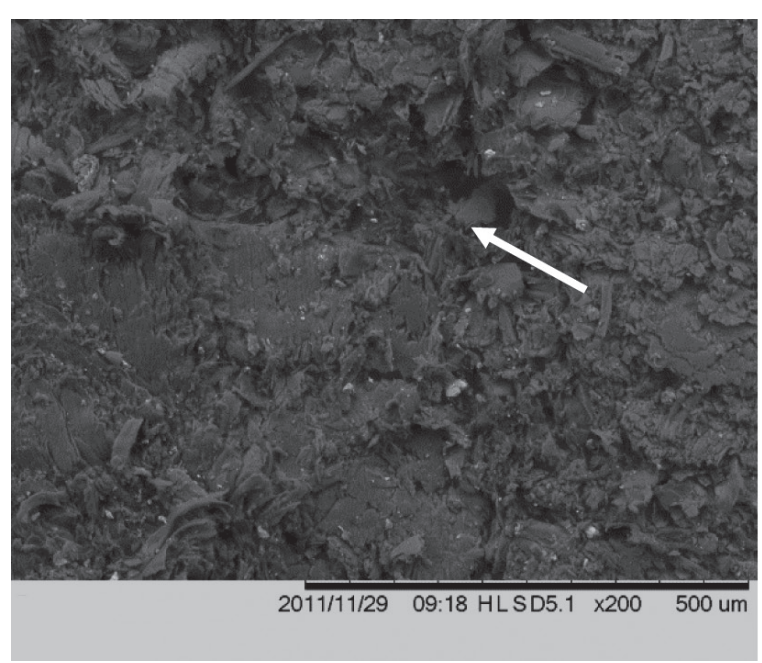

(a)

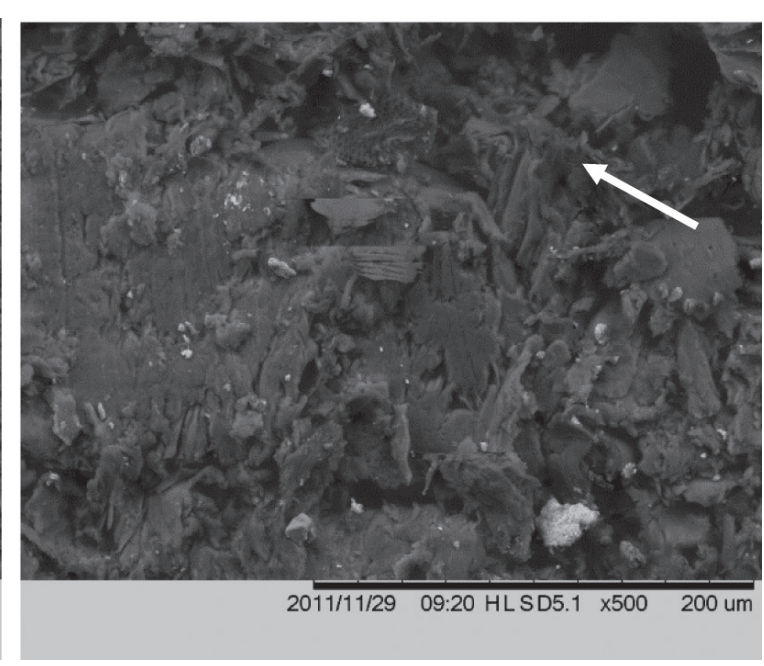

(b)

Figure 12. SEM micrographs of sugarcane bagasse and castor oil resin particleboard (T3) after accelerated aging: a) 150× magnification and b) $500 \times$ magnification.

see that the resin is dispersed homogeneously among the particles, which is essential for the distribution of loads among the fibers of composite materials ${ }^{27}$. Comparing these micrographs with those in Figure 10 (T1), (a) and (b) under different magnifications, it is clear that the resin is not distributed homogeneously among the particles (the light areas represent points of adhesive concentration), impairing their bond strength. This result was attributed to the fiber length $(5 \mathrm{~mm})$.

Figure 12 (T3) shows particle degradation and disruption after accelerated aging, which directly affected the performance of the particleboards, since the particles are responsible for bearing the mechanical loads applied on the composite material ${ }^{23}$.

\section{Conclusions}

Sugarcane bagasse, an agroindustrial waste produced abundantly in Brazil, is a promising material for the manufacture of particleboard. This study presents a new alternative for particleboard production in the laboratory from sugarcane bagasse particles using castor oil-based polyurethane adhesive.

Based on the tests performed in this study, the particleboards made of sugarcane bagasse and castor oil-based two-component polyurethane adhesive, using an $8 \mathrm{~mm}$ fiber length and $1.0 \mathrm{~g} . \mathrm{cm}^{-3}$ density (T2), presented sufficiently satisfactory mechanical properties for use in civil and agricultural construction, as well as in homes, farm buildings and structural applications. 
The accelerated aging test indicated that the particleboards prepared in this study, whether or not coated with waterproofing product, are suitable for use in environments with low exposure to moisture.

The SEM micrographs indicated that castor oil-based two-component polyurethane adhesive fills the interparticle spaces homogeneously when these particles are $8 \mathrm{~mm}$ long,

\section{References}

1. Iwakiri S, Shimizu J, Silva JC, Meness CHSD, Puehringher A, Venson I et al. Production of plywood panels of Grevillea robusta A. Cunn. ex R. Revista Árvore. 2004; 28:883-887.

2. Okino E, Andahur JPV, Santana MAE and Souza MR. Physicomechanical properties of chemically modified sugarcane bagasse particle panels. Scientia Forestalis. 1997; (52):35-42.

3. Contreraras WM, Owen ME, Ballester VC, Contreras Y, Garay D. Design of Particle Tableros de Caña Brava y Adhesivos Phenolformaldehyde. Revista Forestal Latina. 2006; (39):39-55.

4. Battistelli RAG, Marcilio C and Lahr FAR. The use of sugarcane bagasse (saccharum officinarum) and stem leaves of the bamboo species Dendrocalamus giganteus in the production of particle panels. Minerva Journal. 2009; (3):297-305.

5. Silva AJP, França Santos WL and Lahr FAR. Partículas longas e orientadas de bagaço de cana-de-açúcar na produção de painel similar ao OSB. In: Proceedings of the 11th Encontro Brasileiro em Madeira e Estruturas de Madeira; 2008; Londrina. Londrina; 2008. CD-ROM.

6. Mendes RF, Mendes LM, Guimarães Júnior JB, Santos RC and Bufalino L. The effect of adhesive on the properties of particleboards made from sugarcane bagasse generated in the distiller. Revista de Ciências Agrárias. 2010; 32(2):209-218.

7. Guler C, Copur Y and Tascioglu C. The manufacture of particleboards using a mixture of peanut hull (Arachis hypoqaea L.) and European Black pine (Pinus nigra Arnold) wood chips. Bioresource Technology. 2008; 99:28932897. PMid:17689074. http://dx.doi.org/10.1016/j. biortech.2007.06.013

8. Chamma PVC and Leão AL. Aproveitamento de resíduos sólidos na produção de painéis para aplicações arquitetônicas. Revista Energia na Agricultura. 2008; 23(2):73-87.

9. Gunteki E and Karakus B. Feasibility of using eggplant (Solanum melongena) stalks in the production of experimental particleboard. Industrial Crops and Products. 2008; 27:354-358. http://dx.doi.org/10.1016/j.indcrop.2007.12.003

10. Youngquist JA, English BE, Spelter H, Chow P. Agricultural fiber in composition panels. In: Proceedings of the 27th International Particleboard Composite Materials Symposium; 1993; Pullman. Pullman: Washington State University; 1993.

11. Widyorini R, Xu J, Umemura $\mathrm{K}$ and Kawai S.Manufacture and properties of binderless particleboard from bagasse: effects of raw material type, storage methods, and manufacturing process. Journal of Wood Science. 2005; 51(6):648-654. http://dx.doi. org/10.1007/s10086-005-0713-Z

12. Barros Filho RM, Mendes LM, Novack KM, Aprelini LO and Botaro VR. Hybrid chipboard panels based on sugarcane bagasse, urea formaldehyde and melamine formaldehyde resin. Industrial Crops and Products. 2011; 33(2):369-373. http:// dx.doi.org/10.1016/j.indcrop.2010.11.007

13. Xu X, Yao F, Wu Q and Zhou D. The influence of wax-sizing on dimensional stability and mechanical which contributes to improve the physical and mechanical properties of these particleboards.

\section{Acknowledgements}

The authors gratefully acknowledge the financial support of the Brazilian research funding agencies FAPESP, FINEP and CNPq.

properties of bagasse particleboard. Industrial Crops and Products. 2009; 29(1):80-85. http://dx.doi.org/10.1016/j. indcrop.2008.04.008

14. Araújo LCR. Mechanical and chemical characterization of elastomeric polyurethane materials based on oleochemicals. [Dissertação]. São Carlos: Universidade de São Paulo; 1992.

15. Maloney TM. The family of wood composite materials. Forest Products Journal. 1996; 46(2):19-26.

16. Associação Brasileira de Normas Técnicas - ABNT. NBR 14810: Chip panel sheets-Part 3: Testing Methods, terminology. Rio de Janeiro: ABNT; 2006. 32 p.

17. American Society for Testing And Materials -ASTM. D 1037: Standard Test Method for Evaluating Properties of Wood-Base Fiber and Particle Panel Materials. Philadelphia: ASTM; 1996.

18. American National Standards Institute - ANSI. A208.1: Mat-formed wood particle panel: Specification. National Particleboard Association. Gaithersburg: ANSI; 1993.

19. Santana MAE and Teixeira DE. Uso de bagaço de cana-de-açúcar na confecção de chapas aglomeradas. In: Anais do $7^{\circ}$ Congresso Florestal Brasileiro, Anais do Congresso Florestal Panamericano; 1993; Curitiba. Curitiba: SBS/ SBEF; 1993. p. 667-672.

20. Fiorelli J, Lahr FAR, Nascimento MF, Savastano Junior H, Rossignolo JA. Painéis de partículas à base de bagaço de cana e resina de mamona - produção e propriedades. Acta Scientiarum. Technology. 2011; 33(4):401-406. 10.4025/ actascitechnol.v33i4.9615

21. Ashori A, Nourbakhsh A and Karegarfard A. Properties of médium density fiberboard based on bagasse fibers. Journal of Composite Materials. 2009; 43:1927-1934. http://dx.doi. org/10.1177/0021998309341099

22. Marcilio C, Battistella RAG and Valarelli ID. Manufacture of particulate composites of crushed sugarcane leaves and bamboo stem fibers: physical and mechanical characterization. In: Proceedings of the 11th Brazilian Conference of Wood and Timber Structures; 2008; Londrina. Londrina; 2008. CD-Rom.

23. Tabarsa T, Ashori A and Gholamzadeh M. Evaluation of surface roughness and mechanical properties of particleboard panels made from bagasse. Composites: Part B. 2011; 42:1330-1335. http://dx.doi.org/10.1016/j.compositesb.2010.12.018

24. Fiorelli J, Curtolo DD, Barrero NG, Savastano Junior H, Pallone EMJA and Johnson R. Particulate composite based on coconut fiber and castor oil polyurethane adhesive: An ecoefficient product. Industrial Crops and Products. 2012; 40:69-75. http:// dx.doi.org/10.1016/j.indcrop.2012.02.033

25. Lepage ES. Manual de Preservação de Madeiras. Instituto de Pesquisas Tecnológicas de São Paulo; 1986. p. 193-207.

26. Garzon Barrero NM, Fiorelli J, Rossignolo JA and Savastano Junior H. Adjustment methodologies for durability evaluation of particle boards. In: Anais do Workshop de Integração da Rede de Pesquisa INOVATEC FINEP; 2012; Pirassununga. FINEP; 2012.

27. Callister WD. Ciência e Engenharia de Materiais: Uma Introdução. 5. ed. São Paulo: LTC; 2002. 